Ramsay Burt (rburt@dmu.ac.uk) is Professor of Dance History at De Montfort University, UK. His publications include The Male Dancer (1995, revised 2007), Alien Bodies (1997), Judson Dance Theater (2006), Writing Dancing Together (2009) with Valerie Briginshaw, Ungoverning Dance (2016) and British dance: Black routes (2016) with Christy Adair. With Susan Foster, he is founder editor of Discourses in Dance. In 1999 he was Visiting Professor at the Department of Performance Studies, New York University. In 2010 he was Professeur Invité at l'Université de Nice Sophia-Antipolis, and he is a visiting teacher at PARTS in Brussels.

\title{
Avoiding Capture
}

\section{Ramsay Burt}

\begin{abstract}
This essay discusses three recent British contemporary dance works that radically rework the spatial relation between audience and performer. These are: Nicola Conibere's Assembly (2013), Katye Coe's (To) Constantly Vent (2014), and Alexandrina Hemsley and Jamila Johnson-Small's Voodoo (2017). The essay draws on Henri Lefebvre theorization of the social and political production of space to analyze the kinds of reworkings of space time that these works enact. It argues that the works evade capture by the apparatuses that maintain normative ideologies, not only those governing the reception of art but also the apparatuses of racial classification.
\end{abstract}

Key words: logic of visualization; Lefebvre; Nicola Conibere; Katye Coe; Project O; rhythm pattern; apparatus of capture; contemporary dance;

In the search for new structures of knowledge and alternative ways of thinking and relating with others, the way that some recent dance pieces radically rework the spatial relation between audience and performer deserves serious attention. The kinds of work I am thinking of here are ones that are either performed outside conventional theater spaces or rearrange a theater space in an unconventional way. In particular I'm concerned with how reconfigurations of the relationship between dancer and audience member can open 
up new ways of experiencing this relationship. Valerie Briginshaw has written about the social construction of the space of dance performance and the mutual construction of dancing bodies and spaces $(2001,20)$. Citing Henri Lefebvre, she discusses spatial practices that open up particular ways of experiencing space while at the same time limiting imagination and closing down possibilities for creating meanings (13). Choreography that troubles or disrupts these constructions of bodies and spaces and, in Lefebvre's terms, diverts "homogenized space to their own purposes" (Lefebvre 1991, 391) can create potentials for eluding normative expectations about dance performance. This essay examines the extent to which these kinds of disruptive spatial practices can produce new kinds of affective relations between performer and audience member. The makers of such dance works, I will suggest, are not just using experimental approaches for the sake of it but are searching for new structures of knowledge and ways of thinking in order to evade capture by the apparatuses that reinforce normative ideologies and maintain hegemony.

The concept of an apparatus of capture (appareil de capture) ${ }^{1}$ was proposed by Giles Deleuze and Felix Guattari in A Thousand Plateaus (1988). It has been taken up by some scholars writing about contemporary dance to describe choreography. Bojana Cvejić uses Deleuze and Guattari's concept to examine the way that the body and movement are captured 'in a composition of variable relations that transform them without mutually identifying them' $(2015,86)$. For André Lepecki $(2007,2016)$ choreography is an apparatus of capture that "simultaneously distributes and organises dance's relationship to perception and signification" $(2007,120)$. Rudi Laermans argues that what he calls "choreography in general" is 'the art of capturing and modulating the audience's sensory 
attention" $(2015,236)$. Whereas these scholars focus largely on aesthetic concerns, Deleuze and Guattari were theorizing the political uses of apparatuses by the state. There are, they propose, two kinds of political sovereignty that capture, one that does so through the imposition of power and charisma and one that does so strategically through treaties, pacts, laws and contracts $(1988,424)$. My concern in this paper is with the way that state apparatuses use both power and strategy to produce spaces that capture dance performance.

Finding oneself captured in some way is an increasingly familiar feature of twentyfirst century experience. In the networked, consumer societies of developed countries, where the pressures of daily life are increasingly complex, it is only too easy to follow others and move in the same direction as them. It is easier, as the Italian philosopher Giorgio Agamben puts it, for a citizen to "leave his [sic] everyday gestures and his health, his amusements and his occupations, his diet and his desires, to be commanded and controlled in the smallest detail by apparatuses" $(2009,22-3)$. What Agamben is describing here is capture by the apparatuses that the state uses to manage and govern its citizens in the interests of corporations as these develop and maintain consumer demand.

Dancers, like other artists, are also targets of the apparatuses of twenty-first century capitalism. Neoliberal policies have restructured the economy of the creative industries through insistence that all aspects of social life, that have not previously been commercial, should be marketized. Pascal Gielen and Paul de Bruyne have pointed out that the creative industries are central to the new business economy $(2009,8)$, while the artist Andrea Fraser sardonically notes "the mythologies of volunteerist freedom and creative omnipotence that have made art and artists such attractive emblems for neo- 
liberal entrepreneurial, ‘ownership-society’ optimism” (2005, 283). Jeremy Rifkin notes that "culture - shared human experience - is now being drawn into the economic realm thanks to the hold the new communication technologies are beginning to enjoy over dayto-day life" $(2000,138)$. But this, as he also notes, is at the cost of commodifying human relationships. Furthermore businesses are now "mining the cultural landscape" by incentivizing "cultural intermediaries" to look for "new cultural trends that can be packaged, commodified and sold in the commercial marketplace" (183). Some recent dance works try to evade capture in order to maintain qualities in human relations that are lost when these are appropriated for profit-making purposes. By doing so they offer an alternative to neo-liberal assertions of freedom of choice and the rights of the individual who, as Ayn Rand puts it, "should exist for his [sic] own sake, neither sacrificing himself to others nor sacrificing others to himself" $(1989,3)$. This essay investigates and assesses the different ways in which some recent British dance works, rather than celebrating individual rights, rethink the spaces of performance of social relations through seeking to evade capture. It does so through examining three dance works - Nicola Conibere's Assembly (2013), Katye Coe's (To) Constantly Vent (2014), and Alexandrina Hemsley and Jamila Johnson-Small's Voodoo (2017). ${ }^{2}$ Coe and Conibere are colleagues. Conibere was one of the curators of the project during which (To) Constantly Vent was presented, and Coe was one of the first group of performers to present Assembly. While there are affinities between these two pieces, Hemsley and Johnson-Small, who collaborate together under the name Project $\mathrm{O}$, are from a younger generation of contemporary dancers with different sets of concerns and aesthetic sensibilities. All three works nevertheless explore what happens to the performer audience relation when the normative 
performance space is disrupted or radically reconfigured, and each in varying ways explores ideas that evade being captured by the apparatuses at work within cultural institutions.

Theater Space and the Logic of Visualization.

Henri Lefebvre criticized "the notion of a space which is at first empty but is later filled by a social life and modified by it" (Lefebvre 1991, 190). As I have already noted, in his view, space is constructed in ways that enable certain kinds of actions while inhibiting others. Feminist geographer Doreen Massey argued that, rather than thinking in terms of social phenomena taking place in particular spaces, we should recognize that "both social phenomena and space are constructed out of social relations.... The fact is, however, that social relations are never still; they're inherently dynamic" (Massey 1994, 2). We need to be aware that "the spatial is an ever-shifting social geometry of power and signification" (3). This geometry holds in relation three axes along which space is produced. In Lefebvre's theorization, these are: first, the spatial practices of a society that produce space; second, the space of representation, by which Lefebvre means "space as it is conceptualized by scientists, planners, urbanists, technocrats' and similar specialists; and third, representational space, space as it is directly lived through its associated images and symbols" $(1991,39)$. Together, these three account for space as it is perceived, conceived, and lived.

A theater building is an example of a space that is organized in ways that produce the relation between performer and audience during the event of attending a performance. The proscenium stage has evolved in ways that determine a particular kind of social 
relation. ${ }^{3}$ Maaike Bleeker proposes that this produces "a scenographic space in which all that is seen is staged for a viewer" $(2008,15)$. This she argues, creates:

the aesthetic logic of the dramatic theatre [that] presents the audience with a stable and detached point of view, allowing spectators to project themselves into the onstage world. This simultaneously brings the spectators closer to the world onstage, while creating a distance from their bodies as the loci of their looking. (15)

This detached, primarily visual experience has the effect of minimizing the contribution that the other senses make to perception of space during the performance event. This is particularly relevant to dance performance since one's perception of dance involves different senses working together, so that when one watches dance one does so with what philosopher Michel Bernard calls a "listening eye" (1993). Where dance is concerned, the proscenium theater is a space that priorities visual perception through detached acts of seeing, producing a critical distance between performer and spectator. As feminist geographer Gillian Rose explains "the claim to see all and therefore know all depends on assuming a vantage point far removed from the embodied world" $(1993,70-71)$. This could be described as an individual's right to see without the distraction of being physically affected by or affecting others. The spatial divide between audience and performers within the proscenium theater dictates what Lefebvre calls a logic of visualization. This I take to be a set of protocols that make a particular way of looking seem natural or inevitable. The proscenium theater produces a space whose logic of 
visualization establishes detached, individualistic spectatorship - the right to see - and minimizes the effectiveness of other modes of sense perception.

Lefebvre's account does not reduce the production of space to a closed, totalizing system. While space may be conceptualized and organized by technocratic specialists, the way that people use it in everyday life can open it up to other kinds of practices and experiences. What Lefebvre called representational space is "the dominated - and hence passively experienced - space which the imagination seeks to change and appropriate" $(1991,39)$. Each of the three dance pieces uses imagination to change and appropriate the otherwise dominated space of dance performance. Lefebvre understood this domination in terms of Gramsci's concept of hegemony - the way a dominant social group wins the consent of other groups by naturalising the interests of the dominant group. Lefebvre set out to "show how space serves [existing modes of production], and how hegemony makes use of it, in the establishment, on the basis of an underlying logic and with the help of knowledge and technical expertise, of a "system". (1991, 11). Thus the proscenium theater systematizes audience performer relations. Hegemony is not static but a continual process of negotiation. As Stuart Hall points out: "Excluded social forces, whose consent has not been won, whose interests have not been taken into account, form the basis of counter-movements, resistance, alternative strategies and visions ... and the struggle over a hegemonic system starts anew" $(2011,727-8)$. Avoiding capture is a strategy of resistance that can be adopted by those who are conscious that their interests are not taken into account.

The time period during which the three dance pieces discussed in this essay have been made is one during which, some political theorists argue, the conjunction of political 
and economic factors that enabled the state to gain consent for neo-liberal policies and maintain its hegemony has been breaking down (Fisher 2009; Hall 2011; Harvey 2010). In the British context, in return for the neo-liberal socio-economic project of marketization, privatization, and the new free-market global capitalism, the state has sought to offer some degree of support for education, health and welfare and to maintain most aspects of civil society. The financial means for making this offer, however, were substantially curtailed by the banking crisis of 2007-09 and its aftermath. Writing in 2011, Stuart Hall argued that "the present crisis looked at first like one which would expose the deep problems of the neo-liberal model. But so far it is a crisis which refuses to "fuse"" $(2011,705)$. This is a moment when dominant ideas are no longer consensual but imposed from above. Mark Fisher (2009) describes the hegemonic consensus about neo-liberalism as "capitalist realism", pointing out that it is easier to imagine the end of the world than the end of capitalism. ${ }^{4}$ As Gramsci famously wrote in 1930: "The crisis [of authority] consists precisely in the fact that the old is dying and the new cannot be born; in this interregnum a great variety of morbid symptoms appear" $(1971,556)$. It is in this interregnum that the dance artists discussed in this essay, who belong to groups who feel their interests have not been taken into account, have sought to use their imagination to rethink the relation between bodies and space outside the terms of a hegemony that is no longer consensual. Mark Fisher argues that: "The tiniest event can tear a hole in the grey curtain of reaction which has marred the horizon of possibilities under capitalist realism. From a situation in which nothing can happen, suddenly anything is possible again" $(2009,87-8)$. Dance works that reconfigure the space of performance, so that the spectator is no longer distanced from the performer but has a 
more direct relation with her or him, explore this situation where new kinds of aesthetic and artistic experiences seem possible again.

The Spatial Practices of Assembly

(Insert Photos 1 and 2 side by side or one half way up and the other half way down here)

Nicola Conibere's Assembly (2013) explores these new possibilities for reconfiguring space and bodies. In this, spectators watch from the edge of the performance space with the dancers in front of them. But the choreography of the performance event itself (and not just the movement material danced in it) makes explicit the way bodies and spaces are constructed out of social relations, doing so in ways that are not apparent in a proscenium theater. In a recent essay, Conibere has given a useful description of what happens in her piece:

A person - let's call her a spectator - decides to enter a room. As she does so, another person - let's call her a performer - enters that room from a different doorway. A straight line of tape stretches across the floor. The spectator is positioned on one side of the tape, and the performer on the other. After a certain period of time and activity the spectator decides to leave the room. The performer sees this, so exits at the same time. Each departs through the doorway by which they entered. $(2017,77)$ 
Conibere recognizes that the piece creates an unconventional performance space. She says it creates "a kind of hybrid aesthetics of the gallery and the theatre by drawing on the established conventions of spectatorship of both" $(78) .{ }^{5}$ The piece was initially presented in an arts center in Nottingham. It was a free performance. One just turned up and waited to be allowed in. ${ }^{6}$

I saw it in Leeds City Library in 2016. The room in which it was presented had double doors in the middle of the wall behind the spectators and a matching double door immediately opposite behind the performers. The person admitting people to the room had a radio which she used to let me in the door at exactly the same time that a performer came through the other door the opposite side of the performance space. I could therefore see and be seen by my 'pair' - or as Conibere puts it "affiliated performer" (79) - straight away. I looked for somewhere to sit, spotted the smiling face of a friend I hadn't seen for months, settled down and then turned to find my 'pair' again. I had moved to my right to find a patch of floor to sit on. My 'pair' moved to her right mirroring my spatial choice. My 'pair' and I looked at one another for a long time before I started to take in what else was going on. There were, I think, fourteen of us in the audience and the same number of performers in the space, just sitting there looking out at us. When someone in the audience got up to leave, one of the dancers turned to walk out the door at the back, both remaining connected right up to the moment of passing through their respective doors. After a short pause another performer and a spectator entered, and the performer began a movement task, standing while swinging one arm back and forward to shoulder height, the others joining in unison. The dancers made eye contact with the spectators, partly as Conibere explains, so that that could see "when their affiliated spectator leaves" (81). The 
dancers in Leeds were fairly diverse; young and old, male and female. Conibere notes, 'a significant number ... have no experience of performing or do not consider it a profession" (82).

Assembly is essentially a self-generating machine. It has a finite series of tasks, and as each new dancer enters the space, she or he initiates a new one of these which, without anything being said or any overt sign, all the other dancers easily pick up - a kind of collective hive brain. These tasks are mostly everyday actions executed in silence which they have all learnt in rehearsals. They include: standing; lying; walking from one side of the space to the other and back; taking a step to the right then a step to the left back again; swinging the arms from the sides up to shoulder height and then back again; bopping along casually in silence to imagined party music, and so on. These are all done in an easy-going way; as Conibere puts it, "unison with rough edges, each performer moving according to their body's needs and energy" (78). The performers know all the tasks and each dancer chooses one as she or he comes in.

I noticed in one of the longer passages of repetitive moment how the performers' mood gradually changed as the task became more automatic and habitual, and the performers somehow less self-conscious, more everyday in their manner, present in the here and now. From my point of view as spectator, I initially took in what they were doing. After a while I became slightly bored, then began to notice the small, singular differences between the ways in which my 'pair' and the performers around and behind her were executing the task.

How long each activity goes on is, in effect, determined by the audience because it is only when one spectator leaves and another comes in that the new performer will initiate 
a new task of their choice. I felt a warm connection with the dancer who was my 'pair'. From time to time we would find each other's gaze again. At one moment, for some reason, we both spontaneously started smiling at one another in a slightly complicitous way. I was not just a passive spectator. We were both affecting and being affected by each other. I was, in effect, making a small difference to the larger performance event that was unfolding. At one moment I tried unsuccessfully to work out which dancers were paired with the spectators sitting around me. Someone I spoke to later evidently had not made such a firm connection with their 'pair' as I had had with mine.

The word 'assembly' has two meanings that are relevant to Conibere's piece. It can mean a coming together of people for a common purpose or shared activity, for example a school assembly. It can also mean the process whereby components are put together, for example the assembly of a flat-pack furniture kit. Conibere's Assembly does both of these. It is a coming together of beholders and dancers for a performance, and the work assembles itself as each new beholder, in effect, is a catalyst, causing something new to happen in the piece. In this sense, it assembles itself out of a series of units of time space. The beginning and ending of each unit are determined by the entrance of one beholder and the exit of another. The spatial distribution of dancers in the room is determined by where the spectator sits in the room as well as the content of the task that the incoming dancer chooses for the group of dancers. Each task has its own rhythm and, because its movements are performed in unison, the dancers create a visual, rhythmic pattern through their movements. This is particularly evident where the task is performed while standing on the spot or only involves a short repeated step. Each rhythm pattern offers a different 
way of experiencing the room because of the way that the bodies and spaces in it are mutually constructing each other for the duration of its performance.

Conibere argues that Assembly "engages a temporality of the gallery that permits spectators to come and go as they please, while occurring within a theatrical spatial organization that clearly delineates performance and viewing areas; a single line of tape stretches across the floor and spectators are asked to remain on one side while performers occupy the other" (78). The tape fulfilled a practical function precisely because nothing else about the room would have indicated where spectators should be. The same uniform non-theatrical lighting illuminated the whole room so that it was more like being in a studio watching dancers rehearse than being in a theater. Despite the unconventional setting for the piece, learnt habits of watching dance in theaters - and what Lefebvre calls their logic of visualization - nevertheless prompted me to look at the dancers in a detached, critical way. At the same time, however, proximity and eye contact created a feeling of intimacy. Rather than being separated from each other by the tape, dancers and spectators could both feel involved in and mutually responsible for the way Assembly proceeded. Each change altered the rhythm pattern of the space so that the room was the scene of a dynamic series of ever shifting processes of interactions that no one - neither dancer nor spectator - witnesses in its entirety.

It would be convenient to be able to conclude that Assembly offered an aesthetic experience that did not recognize the individual's right to see without the distraction of being physically affected by or affecting others. It was an aesthetic experience that largely evaded captured by normative ideologies because it produced a space whose logic of visualization was not that of detached individualistic seeing but one in which the 
senses combined together to perceive the physicality of one's relation with others. [see photos 1 and 2] Conibere has briefly commented on Judith Butler's writings about assemblies where bodies occupy public spaces in ways that channel the performativity of political activism (Butler 2015). Conibere asserts, however, that Assembly "suggests that the impulse to gather is also an impulse to be vulnerable" $(2017,84)$. I concede that ideologies were still at work in Assembly because of the persistence of habitual modes of spectatorship. These, however, existed in tension with the piece's unconventional ways of dealing with the time space of performance which itself generated new ways of sharing affects between performer and spectator. Unless one is vulnerable one cannot be open to being mutually affected by and affecting others, and I argue that this mutual entanglement is one where the personal touches on the political.

Strategies for Avoiding Capture: Voodoo

Voodoo is an eight-hour immersive performance in four parts that Alexandrina Hemsley and Jamila Johnson-Small, who collaborate together under the name Project $\mathrm{O}$, have been developing and presenting since 2015. I saw it on May 12, 2017 in the Lilian Baylis Studio at Sadlers Wells Theatre in London. A difference between the production of Voodoo that I attended and Assembly is that the physical space that Voodoo disrupts, and reworks was the space in a theater whereas Assembly was presented in a non-theatrical space. Those in the group of spectators with whom I shared the first two-hour block at the beginning of the eight-hour event were mostly white and middle aged but other groups later in the evening may have been younger and more diverse. This group of spectator participants never sat in the auditorium but were invited to move from one part to another 
of what would otherwise be the stage. As we moved, the stage set of benches and flats was dismantled and reassembled around us. This made it very unlikely that we would relate to this stage in the way we would ordinarily have done during a more conventional dance performance. Our spatial experience was thus literally disorienting as our shifts from one spot to another were deftly choreographed by Hemsley, Johnson-Small and their assistants, Fernanda Muñoz-Newsome, Malik Nashad Sharpe, and Katarzyna Perlak. Here is an approximate description of what I experienced as part of the audience. ${ }^{7}$ Our entrance was organized. All of us waited in line at the door to the auditorium to be taken in small groups into it by one of the assistants. The latter were dressed in long futuristic gowns of quilted black cotton. We were each given the programmed and a square black envelope to put our phones and watches in, and personally seated, one by one, alongside those ahead of us to watch a digital projection of scrolling text. This combined historical events during the last fifty years with events from Hemsley and Johnson-Small and their families' life stories. These included, for example, Malcolm X's murder, and later Johnson-Small's mother caught in the Brixton Riots. Hemsley and Johnson-Small were seated imposingly in the space behind us wearing similar outfits to the assistants in white or unbleached cotton, platform heeled boots and dark glasses. They entered the space between us and the screens for some movement, went behind the screens to pass through our midst to the space behind us where they were reborn out of cotton cocoons holding bags of bones. Meanwhile the assistants dismantled the screens and the low benches on which some of the audience had been seated. Balloons were burst, and bones scattered. We were invited to enter the space and lie down on the floor with our eyes closed and then taken through an anatomical image-based relaxation 
exercise. At one point, Hemsley and Johnson-Small each sat with a few spectators one by one, leaning against them in a friendly, intimate way. Towards the end we were all invited to get up and dance together in the space to very sophisticated electronic dance music by Verity Susman. ${ }^{8}$ As we danced, Hemsley and Johnson-Small circulated so that they danced with or near everyone. A few audience members chose not to participate in the communal parts of the performance but, mostly, Voodoo created a space in which one could be part of a communal experience. These then were the fluid dynamic range of shifting spaces and changing rhythm patterns through which we related with the performers and their assistants and with fellow spectators during Voodoo.

Voodoo reconfigured the space of performance so that the spectator had a much more direct relation with Hemsley and Johnson-Small than is possible in a proscenium or black box theater. The space was treated in such a way that a normal theatrical space never materialized, and the performers were never subject to the logic of visualization that a conventional theater space prescribes. The strong impact of the insistent pulse in Susman's music as well as the dancing made the experience of Voodoo more like being in a club than a theater. Fred Moten proposes that "If the sensual dominance of a performance is visual (if you're there live at the club) then the aural energies emerge as that which is given its fullest possibility by the visual" $(2003,172)$. The physicality of the dancing and of participating in the dancing, together with the intensity of the music, channel the impact of Voodoo towards lived experience rather than the visual aspects prioritized by the theater's logic of visualization.

I argued earlier that the formal and aesthetic strategies applied within Assembly have the effect of producing time spaces which disrupted the theater's logic of visualization. 
What is a consequent effect in Conibere's piece becomes politically significant in Voodoo because of the way it opened up the space of a London theater that plays such a central role in supporting contemporary dance as an institution in the UK. Voodoo stimulated a range of sensory perception that the theater's logic of visualization works to foreclose. Lefebvre's understanding of institutions is useful here. He proposed that "The state and each of its component institutions call for spaces - but spaces which they can organize according to their specific requirements' $(1991,85)$. This leads, he argues, to an uneven struggle between institutions whose spatial practices seek to rationalize and systematize space, and users who strive to appropriate it through forms of self-management (autogestion) or "to change life and to transcend political institutions" (92). I understand this as a struggle between the power of the state and movements for radical, democratic change. Project O describe their work as "a contemporary struggle" - the URL for their website is www.acontemporarystruggle.com. This raises questions about artistic practices that critique aspects of the very institutions without which the artists would not be able to produce work.

An institution serves and promotes a particular purpose; in the case of a theater this is the appreciation of performance. The institution organizes the way people engage with this by ordering and regularizing spatial practices and forms of behavior that occur while attending a performance. The artist Andrea Fraser argues that artists are part of the institution so that: "It's a question of what kind of institution we are, what kind of values we institutionalize, what forms of practice we reward, and what kinds of rewards we aspire to" $(2005,283)$. As I noted earlier, Hemsley and Johnson-Small are from a younger generation to Coe and Conibere. They are also black British artists whose work 
straddles contemporary dance and live art. In a programmed note Hemsley and JohnsonSmall state that, in Voodoo, they "dance themselves out of a desire for and expectation of aesthetic assimilation that upholds white supremacy" (Project O, 2017). Assimilation involves self-censorship, erasure of differences that one pretends don't exist. Voodoo, however, is a vehicle through which Hemsley and Johnson-Small present differences that are meaningful to them and invite spectator participants to find these meaningful too. Whereas Assembly creates an alternative space that disrupts the normative logic of visualization, Hemsley and Johnson-Small are more concerned with escaping from the ways in which cultural trends can be captured and commodified, stifling the meaningfulness of difference. To understand the complex political basis underpinning their approach in Voodoo and the particular aspects of the logic of visualization that it disrupts, it is necessary, before discussing Voodoo further, to examine two videos, both from 2016: Hemsley's Google Ghosts and Johnson-Small's One Big Fist which both anticipate Voodoo's strategies and concerns.

In Google Ghosts, which Alexandrina Hemsley posted on Vimeo and describes as "A composition between Google algorithms and me," we see half-formed words and phrases typed into a Google search bar which the research engine, using machine learning to look for matches in huge sets of data, attempts to complete with ghostly grey suggestions. ${ }^{9}$ Suggestions for completing the half question "where is society" include "society nightclub Belfast", "society6" (a web platform for visual artists), and more aphoristically "where is society headed." "Women" becomes women's boots, books, and clothes.

"Women need" is completed with "more sleep than men" and "men". Some of the typed half statements touch on identity. "Men need" offers advice about "what men want in 
relationships" and "want to know what makes guys stay?" There are, however, no suggestions for completing the half sentence "Trans women need." Other search terms typed in include "black women are" and "mixed race." Suggestions for completing "How to survive" include "my period," "my marriage" and "my job." When I myself type some of these into the Google search bar on my computer, I get different results. In Google Ghosts, the search engine appears to have deduced that Hemsley is female and a woman of color.

I googled the words in Google Ghosts's soundtrack and found it is the 2016 House hit "Rinse and Repeat" by the British DJ Riton with vocals by Kah-Lo. The words 'then we rinse and repeat' and the chorus 'and it just goes on' are an approximate description or commentary on the ghostly words that Google continually generates throughout the video. What the ghostly grey letters propose are a bewildering variety of different topics and concerns ranging from banal aphorisms to invitations to purchase consumer goods and services. As Hemsley types in these incomplete searches into the search bar, supposedly trying to find something out, the software program powering the search engine tries to second guess who she is, what her interests and preferences are. Based on what it already knows from past searches, these are used to establish whether she is "target" or "waste" and thus to monetize this data profitably. Although I might be underestimating the potential of the software program, Hemsley doesn't seem to me to give much, if anything, about herself away during this series of searches. On an experiential level, Hemsley's video presents too much information to take in so that I begin to lose track, while the speed of the typing combined with the techno rhythm of "Rinse and Repeat" has a hypnotic potential. I ride the constant stream of ghostly phrases 
as I ride the beats. The irony is, of course, that I have repeatedly used Google while writing this essay. As a human rather than a computer, my impression is that Hemsley seems to be avoiding capture in order to establish a basis for critical reflection outside the control of the Google Corporation. It exemplifies the extent to which networked, image literate people can see through the tactics of these corporations and open up alternative ways of thinking that can be shared with others.

In my readings of Assembly and Google Ghosts, I have been identifying ways in which the artists and performers are attempting to escape capture in order to open up physical spaces or a conceptual basis for thinking differently. This poses the questions for performing artists: what does capture mean? and what possibilities are there for turning away from it or turning it around? In his 1993 book, The Coming Community, Giorgio Agamben argued that the possibility of not taking up any identity whatever is a threat that the state cannot come to terms with. In 2006, the French Tiqqun Collective described the "normal" man in the street as a Bloom - a reference to Joyce's Ulysees. For Agamben, he is "The harmless citizen of postindustrial democracies (the Bloom, as it has been effectively suggested he be called), who readily does everything that he is asked to do..." allowing, as I noted earlier, his gestures, his health, his amusements, his diet and so many other aspects of his everyday existence to be captured by apparatuses $(2009,22-3)$. The search engine that Hemsley plays in Google Ghosts is one of the apparatuses that command and control twenty-first century citizens through the normalizing options it has to offer. As I've noted, the speed and complexity of Google Ghosts has the effect of overloading me with information. As Franco 'Bifo' Berardi notes: 
In a hypercomplex environment that cannot be properly understood and governed by the individual mind, people will follow simplified pathways and will use complexity-reducing interfaces. That is why social behavior today seems to be trapped into regular and inescapable patterns of interaction. (2012, 15-16)

What Google Ghosts encourages the spectator to do, however, is to focus on the dynamic flow of music and image that Hemsley creates in this video as well as on the information and the ghostly grey suggestions. Doing so has the effect of opening up a potential for thinking and acting differently.

In the political manifesto, L'insurrection qui viens (The Coming Insurrection), the Invisible Committee / Tiqqun Collective recommend fleeing from visibility as an activist strategy: "Not making ourselves visible, but instead turning the anonymity to which we've been relegated to our advantage, and through conspiracy, nocturnal or faceless actions, creating invulnerable positions of attack" (Invisible Committee 2009, 75). As Peggy Phelan has observed, visibility is a trap and "There is real power in remaining unmarked" $(1993,6)$. Dancers, nevertheless, make themselves visible when they perform. At issue is what kinds of visibility have the potential for evading or escaping capture. The manifesto continues: "To be socially nothing is not a humiliating condition, the source of some tragic lack of recognition - from whom do we seek recognition - but is on the contrary the condition for maximum freedom of action" ((Invisible Committee 2009, 6). There is, however, another discourse on invisibility concerning people of color. Performance theorist Fred Moten argues that: 
The mark of invisibility is a visible, racial mark; invisibility has visibility at its heart. To be invisible is to be seen, instantly and fascinatingly recognized as unrecognizable, as the abject, as the absence of meanings wholly independent of any influence of the vessel itself. $(2003,68)$.

What prompted Moten to write this is Ralph Ellison's novel Invisible Man. In the prologue of this novel, its narrator explains "I am a man of substance, of flesh and bone, fibre and liquids - and I might even be said to possess a mind. I am invisible, understand, simply because people refuse to see me" $(1952,3)$. Ellison implies but never actually says outright that he is invisible because of his dark skin. He is, in Lefebvre's terms, “entirely subordinated to the logic of visualisation' and there is no recognition of 'lived aspects of [his] spatial existence" (1991, 127-28).

In Google Ghosts, the typist exploits her lack of visual presence to escape the logic of visualization. When the Tiqqun collective advocate invisibility, they have not considered that, from the point of view of people like Ellison's narrator, invisibility can be the source of a dehumanizing lack of recognition. He wants to be visible. Running through Google Ghosts (and through Project O's work as a whole) is this tension between, on the one hand, the strategic value of invisibility in evading the mechanisms through which institutions and corporations seek to identify and label their citizens or consumers within a recognized system of classification, and, on the other hand, the need for a non-discriminatory recognition of difference. The deliberately incomplete searches in Google Ghosts, taken as a whole, evade capture in order to regain freedom of action. 
This is to turn away from, or turn around, controlling apparatuses and create a potential for thinking differently. This is what I am suggesting the choreographic and verbal turns that I am discussing achieve.

In Jamila Johnson-Small's One Big Fist, the video editing makes her dancing seems minimalist and mechanical through its almost migraine-inducing repetitions. ${ }^{10}$ It consisted of close shots of Johnson-Small, wearing metallic silver boxer shorts and a red bikini top, dancing and turning from side to side. For most of the piece, the video frames her body from mid-thigh to navel, with her hand occasionally passing through the shot. It also shows the area from her bikini top to her nose, and then later her head and shoulders, though she never acknowledges or looks directly at the camera. It is edited almost like stop frame animation giving it a machine-like quality, not jerky but fluidly mechanical. The relation between sound and movement is important. It has a satisfying density through its layering of sounds, words, and images. The music is fast and continuous with sudden changes and breaks for spoken words. The dance material keeps up its pace but occasionally slows down or freezes, or there is a cut to a blacked-out screen. JohnsonSmall made the sound edit in parallel with the video. In it I recognize bits of Steve Reich's Piano Phase which Anne Teresa de Keersmaeker used in her classic early work Fase. A voice sings the words of the refrain "take me to the edge of explosion." I googled this and found it comes from "Take me baby", a techno classic from 1994 by the Finnish musician Jimi Tenor. But here the words are sung by female voices instead of Tenor's gruff male one. The words "all my education has been misleading," are spoken and these come from one of Johnson-Small's blog posts (2016b). 
The editing of the filmed movement material is highly fragmented and almost machine-like in its repeats, almost like the manipulation of media in Glitch Art. ${ }^{11}$ In Kodwo Eshun's terms, Johnson-Small technofies ${ }^{12}$ her movements: in Eshun's account "To technofy is to become aware of the coevolution of machine and human, the secret life of machines, the computerization of the world, the programming of history, the informatics of reality" $(1998,103)$. The close-ups of hands and fingers at the beginning are particularly difficult to read. Visually they are almost an assault, invading the intimate space that would be close up and personal if I were there in the space occupied by the video camera. The effect of the flickering editing seems to me to be almost deliberately trying to make the video hard to watch, although it nevertheless builds a trance-like intensity. Eshun proposes that "to technofy is to optimize the machinic mutation of music" (104), and this suggests seeing One Big Fist as the optimization of the machinic mutation of her dancing. For me it is as if her video offers but at the same time withholds - not as some sort of tease but as if bound in an irreconcilable tension. Johnson-Small's presence seems pulled painfully between the pleasure of being in technofied motion and the stress of having to deal with how this dancing reads within the politically and culturally constructed condition of image production.

The film's clos-ups create a virtual space that feels intimate. Psychologist J.J. Gibson (1950) argued that two-dimensional photographs and film afford the viewer with the potential to perceive three-dimensional spaces. The high definition close-ups give tactile information about her brown skin. I have already alluded to the politics of skin color. Ralph Ellison's narrator, while not naming it directly, noted that his invisibility was not "exactly a matter of a bio-chemical accident to my epidermis" (1952, 3). His invisibility 
was the result of a logic of visualization whereby differences in social and cultural experiences are reduced to a visual sign, skin color, that is used to place subjects within a system of racial classification. Stuart Hall has analyzed the politics of skin color and "epidermal schemas", arguing that it underpins:

a social system [that] requires that we think not only about the relations which sustain it but also about how, day to day, it is reproduced. This in turn takes us to questions of gendered bodies, of sexualities, and of the manifold transactions between variant 'epidermal schemas' on the one hand, and erotic desire on the other. It brings us to the conjunction of race and sexuality. $(2017,102)$

One Big Fist is a performative intervention within these transactions and conjunctions. Johnson-Small has written: "I expose myself because I see many bodies, but I don't anywhere see bodies that move like mine about the world" (2016a). Although she was not directly discussing One Big Fist, this nevertheless poses the question how to achieve the visibility that Ellison's narrator wanted without suffering oppression under the social system that Hall identifies.

Johnson-Small is black and female. I am white, privileged and male. I was in my mid 30s when my University first connected to the world wide web, whereas for people of her generation the internet has existed all their lives. There are aspects of One Big Fist, particularly relating to race and sexuality, that I have to work to try and understand. She writes about "attempting to shoulder a ton of bricks and a face full of abuse with a body growing curvaceous in ways no-one had warned me about" (2016a). By speaking about 
her lived experience she is challenging a racist logic of visualization that subordinates her within a racial system of classification. The physical information afforded by the video, including the particular quality of her movement and the way this embodies the energy of the music, helps the video to escape this reductive, visually based system of racial classification. Her edited movements create a dynamic rhythm pattern in which body and the virtual space of the video screen are constructing each other. One Big Fist allows the machine-like energy of the music to emerge so that the dancer has more than just a fashionable appearance that, on its own, can be captured and monetized. By allowing the lived experience of moving to music to dominate, and presenting differences that are meaningful to her, One Big Fist breaks free from the logic of visualization.

One Big Fist employs a strategy of withdrawing and not playing the capitalist game through the kind of radical passivity that Agamben, The Invisible Committee, and Berardi advocate. Berardi proposes:

Capitalism is demanding participation, collaboration, active intervention in the economy, competition and entrepreneurship, critical consumption, constructive critique. All this is fake. Radical passivity means active withdrawal, and withdrawal means creating spaces of autonomy where solidarity can be rebuilt, and where selfrelying communities can start a process of proliferation, contagion, and eventually of reversal of the trend. $(2011,177)$

Johnson-Small's danced self-exposure opens up a basis for that elusive element which, in Agamben's terms, seems to escape the grasp of the apparatuses of the state and of global 
capitalism. This is somewhere under the radar. In this, it is possible to turn around and away from these apparatuses and open up potentials for what Berardi calls self-relying communities who may think and act differently about things like de Keersmaeker's contemporary choreography, electronic dance music, black feminist identities, sexualities, and education that misleads. It is this kind of self-relying, dancing community that Project $\mathrm{O}$ brings into being for the duration of Voodoo.

I argued earlier that the ways Voodoo reworked the physical space of the Lilian Baylis Theatre disrupted the logic of visualization that the architecture of conventional theater space imposes. Through my discussion of Google Ghosts and One Big Fist, I have identified another logic of visualization produced by a system of racial classification. I have argued that the compositional practices that Hemsley and Johnson-Small adopt in these two videos draw attention to and frustrate this racist logic of visualization. The same practices have been used in Voodoo. This is evident in their similar use of electronic dance music that has its roots in the African diaspora. I noted earlier that Hemsley and Johnson-Small make a big claim for Voodoo in the program where they state that they dance as they do in order to avoid being assimilated into normative aesthetic values that uphold white supremacy. Both their own movements and the participatory dancing that they initiate in Voodoo create spaces and bodies that evade capture by exploiting the strategic value of the kind of resistance to visibility I have identified in Google Ghosts and One Big Fist. Voodoo does not hide the fact that its makers are concerned with the politics of representation. The program proposes that Voodoo's: 
durational unfolding becomes a science fiction that addresses the desire, confusion and responsibility of being a single subject who is also a symbol of many longpersecuted people ... An attempt to never be caught or trapped, to visit and leave behind former selves, to move and to transform. (Project O 2017, ellipsis in original)

When Hemsley and Johnson-Small refer here to science fiction what they say resonates with the theoretical ideas that have developed around the idea of Afro-futurism. This is not a science-fiction genre as such but embraces literature, popular music, fashion and other cultural forms. Ralph Ellison's novel has been claimed as its precursor as well as Sun Raa and George Clinton's pop videos and stage acts, together with sci-fi novels by African American writers like Octavia Butler and Samuel R Delaney. In a seminal 1994 essay, "Black to the future", Mark Dery notes that 'African Americans, in a very real sense, are the descendants of alien abductees' and that "the notion of Afro-futurism gives rise to the troubling antinomy: Can a community whose past has been deliberately rubbed out, and whose energies have subsequently been consumed by the search for legible traces of its history, imagine possible futures?" $(1994,180)$. The science-fiction novelist Nalo Hopkins argues that "it's important to make and claim space in that envisioning [of the future], space for the way in which marginalized people experience the world and hope for the future" $(2005,103)$. Voodoo begins by writing black British subjects in the present into a global past, and then moves through a futuristic rebirth to imagine possible futures, taking its audience participants with them. It creates a physical and ideological space that is incompatible with a logic of visualization that naturalizes the right to see without being affected by others or affecting them, affording instead the potential for 
non-discriminatory recognition of difference. The strategies that Hemsley and JohnsonSmall deploy for disrupting logics of visualization and evading capture create new bodies and spaces that hint at new structures of knowledge and alternative ways of thinking and experiencing existence.

The Creative Rupture of (To) Constantly Vent (2014)

(Place Photos 3 and 4 here side by side or one half way up and the other half way down)

I have been in the gallery for nearly three quarters of an hour. I know that she is running circuits through it and I'm getting concerned that I still haven't seen her since that's really why I have come rather than to look at the works in the exhibition. Somehow I have managed to be in the wrong places at the wrong times and kept missing her, or perhaps I've been in places that were not part of the circuit? I decide to explain it to the Gallery Attendant and ask if he can help He knows all about it, of course, and tells me I have just missed her and suggests which level I should go to in order to catch her. I do so. After I have been half looking for a bit at some huge colour photographs and video installations of volcanic landscapes in Iceland, I catch sight of her out of the corner of my eye. Or rather I spot two of them - which is not what I was expecting - wasn't it supposed to be a solo practice? They run down the stairs, through the gallery, past some speakers that are relaying the sound of their running, and the two of them disappear down a ramp to the level below. If this were a more conventional performance, I would watch it carefully, move to follow her, and make sure that I saw as much as possible. That doesn't seem appropriate now. I don't want to stop and watch but just let it happen and pass on. 
Once I've seen her, or them, there seems nothing more to see. But there seems to be so much compressed into that brief duration when she registers on my consciousness even though - or perhaps precisely because - there was nothing to it - or very little, almost nothing.

This is a brief account of a visit to the Hayward Gallery in London in November 2014 to experience Katye Coe's (To) Constantly Vent. ${ }^{13}$ [see Photo 3 and 4] Like Conibere's Assembly, Coe's (To) Constantly Vent produces time spaces that evade capture by the state's apparatuses at work within a logic of visualisation. Coe's strategies for evading capture are political in a very different way from those used by Hemsley and Johnson-Small because of the way Coe uses the institutional space of an art museum rather than a theater building. It was a work presented at the Hayward Gallery as part of the Volumes Project, a group of performances curated by Frank Bock, Nicola Conibere and Martin Hargreaves, that were presented during the exhibition Mirrorcity. ${ }^{14}$ In (To) Constantly Vent, a group of runners who were also dancers or performers ran solo continuous circuits through the exhibition and outside on the South Bank and into the wider cityscape. Coe's piece was presented for twelve hours a week for twelve weeks of the exhibition.

(To) Constantly Vent crossed or transgressed many different kinds of boundaries. During their three-hour solo shifts (or sometimes two shared, relay shifts, each of one and a half hours), each runner passed regularly in and out of the building and through the exhibition spaces. Through the kind of performative presence she or he expressed, each crossed interpersonal boundaries when momentarily and unintentionally connecting with someone either in or outside the gallery. Coe later explained that what I saw was the 
change-over between two runners. ${ }^{15}$ If there are two people on a shared shift then they arrange for there to be a change-over between the two. Sometimes one runner waits outside the gallery and they change, but sometimes they both do a circuit together through the gallery. She also told me that the runners are covered by insurance while they are in the gallery but not when they leave it to run the part of the circuit outside. The insurance is primarily concerned with what things in the gallery are worth. One set of sculptures are considered too fragile for them to run in their vicinity. When they approach other sculptural works, for safety reasons they have been instructed to run between people and the work and not the other way round. So the circuits they run and the kinds of interactions they can make are determined by various factors and contingencies including the needs of the runner, the terms of the insurance, and where gallery visitors are in a gallery space as the runner passes through it.

The gallery staff see the runners more than anyone else. The people who are taking the tickets at the door have to let the runners in. Coe discovered that they are managed by different supervisors from the Gallery Assistants whose jobs have been outsourced to a security firm. The runners share a rest or mess room with the Gallery Assistants. Organisationally the project, therefore, involved communication and negotiations including those between dancers, with the curatorial team, the exhibition's insurers, and with ticket staff and Gallery Attendants.

In Lefebvre's terms an art gallery is an institution that systematises spatial practices and forms of behaviour that occur while viewing an exhibition. I noted earlier Conibere's observation that in an art gallery, the visitor can come and go as they please. The way the art works are arranged and displayed - for example chronologically or thematically - 
encourages a visitor to pass through the exhibition in a particular order. Individuals nevertheless make their own choices about which works in a particular room to look at and how long to stop before each work. Each visitor's journey through the exhibition has its own rhythm of strolling, then pausing to look, and then moving on. The institution guards their individualistic right to see without being affected by others or affecting them. The act of running through the exhibition produces a creative disruption. Whereas for the duration of the exhibition the art works are fixed while the visitor moves from one to another, (To) Constantly Vent is an ephemeral event where an artistic product circulates at speed. Indeed, it was so ephemeral that I almost missed it. What it therefore disrupts is the ideological nature of the way in which the art gallery as an institution organised the time space of the exhibition. The runners are not agents of what the economist Jospeh Schumpeter called creative destruction (Schumpeter 1942). Whereas Schumpeter argued that capitalism periodically needs disruption in order to produce innovative new ways of extracting profits, the runners do not produce anything from which profit could be extracted. Their disruption creates affective experiences that evade capture.

(To) Constantly Vent runs in and out of the building housing the Hayward Gallery, and, at an organisational level, crosses the boundaries between the different levels in which people work in the institution. One thing that is distinctive about the piece is the kind of access that the runners had to the gallery at both physical and institutional levels. The fact that the runners were allowed ticket-free access to the gallery and did not leave the usual trace is significant. As a result of a recent industrial transformation created by the internet, business models are increasingly built around access and consumer traces. The kind of access that the runners had to the gallery was free of the kinds of control 
systems that generally affect citizens of developed countries. To appreciate the kind of creative disruption engendered by (To) Constantly Vent, it is necessary to examine these control systems more closely.

Jeremy Rifkin (2000) was one of the first researchers in the field of economics and management studies to note the shift, with the rise of internet-based commerce, from selling physical commodities to the leasing of services or experiences. Thus, for example, computer users pay a yearly subscription for anti-virus protection, or pay to view streamed, online movies or episodes of drama series. As philosopher and social theorist Brian Massumi noted in a 2001 interview, the consequent social model is one that relies on gatekeeper functions, checking that a person has the money or the privileges to gain access or pass through a series of points. “The checks don't control you, they don't tell you where to go or what to be doing ... They lie in wait for you at key points. You come to them and they're activated by your arrival" $(2015,26)$. Massumi points out that what is being controlled is passage across thresholds. This is an instance, he argues, of a kind of social organisation that Foucault called a control society. This is different from the disciplinary society that is characterised by the prison, the school and the barracks. The exhibition, as I have described it, does not so much impose discipline on the visitor as exert a degree of control on their spatial and rhythmic behaviour. (To) Constantly Vent, however, escapes such controls.

More recent internet commerce uses strategies for capturing and monetizing data about potential customers as they browse the internet. This was noted in the discussion of Google Ghosts. Joseph Turow (2011) has investigated the way that FinTech (financial technology) companies have developed a "form of social profiling and discrimination by 
customizing our media content on the basis of marketing reputations we don't even know we have" $(2011,2)$. To produce these profiles, cookies are used to look at individuals' browsing histories, and these are taken together with the make of computer or smart phone with which they are browsing, their social media posts and followers, their locations, age, job and other personal metadata. One of Turow's examples is the Acxiom Corporation's Life Stage Clustering System: "PersonicX". According to Acxiom's marketing leaflet, their system enables their clients "to see differences in how U.S. households spend time and money. This turns raw data about customers into accurate, actionable information" (Acxiom 2009, 3). As Turow notes, corporations use systems like this to determine whether a potential customer is "target" or "waste". Targets are investigated further, and their browsing is tracked, whereas "waste" receive lower grade advertising (Turow 2011, 87). ${ }^{16}$ The runners in (To) Constantly Vent however are ambiguously neither target nor waste in so far as they don't register at all within the normal gatekeeping structures of the gallery. At the level of experience, the runners disrupt the spatial and rhythmic parameters governing the behavior of the gallery visitor. At an institutional level, the runners therefore turn spaces that have been divided up into separate administrative territories into one smooth, unbroken space that they speed through energetically.

At issue is not just the fact that the runners are in effect evading being captured by these gatekeeping structures, but the energy with which they do so. For Coe, what is central in (To) Constantly Vent is the quality of attention that the runners have while doing their circuits through the gallery. This is why, she says, the runners need to be dancers or people with experience of performing. Coe herself has been involved for 
many years with dance improvisation practices, and the kind of openness and neutral preparedness that improvisers develop is the quality of performative presence she wants her runners to deliver. They are not representing anything, just running as a simple, unembellished task. In this context she cites the feminist philosopher Karen Barad: "The move toward performative alternatives to representationalism shifts the focus from questions of correspondence between descriptions and reality ... to matters of practices/ doings/ actions" (Barad 2003, 802). Coe observes that everyone knows that running continuously round the Hayward circuit for three hours is hard work: "There's an appreciation of it that is really levelling". This recognition creates alternative potentials for relations between a runner and a gallery visitor (or attendant). Coe gives an example from one of her shifts: 'I caught a guy's gaze for a moment, not on purpose, it was a complete accident and it was a huge moment for him I could tell. He was disarmed and so was I. I'm neither looking for it nor expecting it". And yet it is because of Coe's background in improvisation that she knows how to be open to, and ready in advance for what is happening as it happens, and thus ready for any affective charge that might realize itself in the moment.

Remembering a handover between shifts, when two runners made a circuit together, Coe said 'there is such joy in the moment of companionship, the information exchange is really buoyant. It is a moment where solitude melts away and the relief of ending/ beginning is shared.' So, rather than passing anaesthetically through institutional checkpoints which are activated by their arrival, the runners affect and are affected by others whom they encounter during their circuits. This is what I myself noted on my visit to the Hayward Gallery - that there seemed to be so much compressed into the brief 
moment when Coe passed near me and registered on my consciousness. These intensities of experience are inconceivable within the regularized spatial practices that order the modes of access and behavior that art museums and galleries facilitate through their logic of visualization. These produce norms with which the visitor unconsciously conforms. The intensities generated during (To) Constantly Vent come into existence through undoing the spatial demarcations that constitute the institution and thus allowing the work's energy to generate the huge moments and the joys that Coe describes. The piece therefore produces affective qualities in human relations that would otherwise be lost when such relations are captured and commodified.

\section{Conclusion.}

Through the discussion of these three performance events, I have argued that bodies and spaces have mutually constructed themselves, creating new ways of thinking and experiencing dance. I have discussed how spectators catalyze mass rhythm patterns in Assembly, how technofied bodies refuse assimilation in Voodoo, and how uncapturable moments of affective exchange take place in (To) Constantly Vent. I have shown through readings of these pieces that Lefebvre's concept of the logic of visualization is a useful tool for understanding the apparatuses that the state and corporations use to capture and control citizens and consumers. I have argued that there is a tension in Assembly between the normative logic of visualization in a theatrical space and the opportunities for sharing affects between performer and spectator that the work offers. Similarly (To) Constantly Vent creates situations in which affective intensities are released because of the way the piece disrupts the normative logic of visualization of the art exhibition. 
Because Assembly and (To) Constantly Vent share affects, they offer spectators experiences that are not subject to the relations of power imposed by state apparatuses. Conibere is aware of the socio-political aspects of what she is dealing with in Assembly. Her work, I suggest, escapes capture in a more general sense than (To) Constantly Vent because of the way Coe's project involved negotiations with so many different organizational levels of the Hayward Gallery. Voodoo similarly disturbs the logic of visualization of the theater but does so as part of its strategy for disrupting a racist logic of visualization not tied to specific architectural spaces but that is inherent in a system of racial classification, one that reduces complexities of the lived experience of difference to the purely visual factor of skin color. This enables Hemsley and Johnson-Small to present themselves in ways that avoid capture by what they see as the white suprematist apparatus that determines how people of color are expected to become assimilated. At issue here are matters of agency during a period of interregnum when the hegemony of neo-liberal capitalism has been breaking down so that, as Mark Fisher suggests, anything is possible again $(2009,88)$. Performers and spectators in Assembly and (To) Constantly Vent enjoy a degree of autonomy which allows them the freedom to relate with each other in ways I have outlined. People of color cannot take such freedoms for granted but have to work harder to maintain them. For the eight-hour duration of Voodoo, and not just for the period each group of spectators is in the theater itself, bodies become counter-sites that disrupt the social relations normally occurring in a theater and produce time spaces which regain the potential for imagining different futures. By disrupting the architectural space of the theater and by performing in non-theatrical spaces, all three works realize the conditions of possibility for producing new bodies and spaces again. 


\section{Notes}

1 Deleuze and Guattari use the French word appareil while Foucault, Agamben and others use the French word dispositif. Both words mean apparatus. Whereas appareil means an ensemble of elements working together, dispositif refers to the manner in which these are disposed.

2 I am grateful to Katye Coe, Nicola Conibere, Alexandrina Hemsley and Jamila Johnson-Small for their comments on this essay. I am also grateful to 'Funmi Adewole, Helen Thomas, and my two blind readers for their very useful suggestions. Tia-Monique Uzor told me that Alexandina Hemsley and Jamila Johnson-Small saw avoiding capture as one of their artistic priorities during an interview in 2015. See Uzor 2018 p. 44.

3 In the eighteenth century audiences were increasingly discouraged from interacting directly with performers through sitting on or walking across the stage. They were encouraged to see the proscenium as a fourth wall. This way of focusing audience attention, as Jonathan Crary points out, was developed further by Wagner's theater reforms which included darkening the auditorium 'as a way of heightening the intensity of light effects on stage and preventing peripheral distraction' $(1999,251)$.

4 "Capitalism is what is left when beliefs have collapsed at the level of ritual or symbolic elaboration, and all that is left is the consumer-spectator trudging through the ruins and the relics." (Fisher 2009, 4)

5 Both Conibere and Coe have contributed chapters to Sara Wookey's collection on dance in art galleries. See Wookey 2015. For further discussion of Dance and the Museum see the special issue of Dance Research Journal 201446 (3).

6 For full details of all performances see Conibere 2017, 78, fn. 2. 
7 The performance of Voodoo at the Lillian Baylis Studio was billed as the premier, but there had been earlier showings of it as a work in progress at the Chelsea Theatre, November 17, 2015, and as part of the In Between Time festival in Bristol, February 8-10, 2017.

8 At the time of writing, the differences between 'techno', 'house', 'afro-house' music are contested, so I am using the more general term Electronic Dance Music.

9 https://vimeo.com/157127534. Accessed August 23, 2018.

10 It was posted on Vimeo but is no longer publicly available.

11 Glitch Art, sometimes called Dirty New Media, exploits for aesthetic effect what might otherwise be taken to be glitches, bits of corrupted digital media - either in still or moving images or in sound files.

12 Eshun invents this neologism 'technofy' to discuss the affective experience of Detroit techno music. In philosophical terms he alludes here to Deleuze and Guattari's (1988) concept of machinic connection and to Donna Haraway's (1991) development of a discourse about the cyborg.

13 (To) Constantly Vent was previously presented during the 'Dancer as Agent' conference November 23-24, 2013 at DOCH, Dance and Circus School, Stockholm, and during the 'What Now' festival, April 4-7, 2014 at Siobhan Davies Dance studio, London.

14 The Mirrorcity exhibition was curated by Stephanie Rosenthal.

15 All quotations from Katye Coe are from an interview with her in the café at the Hayward Gallery on November 22, 2014. 
16 While this seems to be the state of play at the time of writing, no doubt new uses of data mining will soon make this redundant. 


\section{Works Cited}

Acxiom. 2009. Life Stage Clustering System: "PersonicX” An Explanation of the Development of the PersonicX Clustering System. Accessed November 8, 2017. https://c.ymcdn.com/sites/dema.siteym.com/resource/resmgr/Member_Resources/Lifestage_Clustering.pdf . Agamben, Giorgio. 1993. The Coming Community. Minneapolis, London: University of Minnesota Press.

. Giorgio. 2009. What is an Apparatus? Stanford: Stanford University Press.

Barad, Karen. 2003. "Posthumanist Performativity: Toward an Understanding of How Matter Comes to Matter." Signs 28 (3): 801-31.

Berardi, Franco. 2011. After the Future. Oakland and Baltimore: AK Press. . Franco. 2012. The Uprising: On Poetry and Finance. Cambridge, Mass: Semiotext(e).

Bernard, Michel. 1993. "Sens et fiction: ou les effets étrange de trois chiasmes sensoriels." Nouvels de Danse 17: 6-64.

Bleeker, Maaike. 2008. Visuality in the Theatre: The Locus of Looking. Basingstoke: Palgrave Macmillan.

Briginshaw, Valerie. 2001. Dance Space and Subjectivity. Basingstoke: Palgrave.

Butler, Judith. 2015. Notes Toward a Performative Theory of Assembly. Cambridge, Mass.: Harvard University Press.

Crary, Jonathan. 1999. Suspension of Perception: Attention, Spectacle, and Modern Culture. Cambridge, Mass.: MIT Press.

Conibere, Nicola. 2017. “Some Bodies.” Performance Research 22 (3): 77-84.

Coe, Katye. (2014) Interview with Ramsay Burt at the Hayward Gallery, London. November 22.

Cvejić, Bojana. 2015. Choreographing Problems: Expressive Concepts in European Contemporary Dance and Performance. Basingstoke: Palgrave Macmillan.

Deleuze, Gilles and Guattari, Felix. 1988. A Thousand Plateaus. Translated by Brian Massumi. London: The Athlone Press.

Dery, Mark. 1994. "Black to the Future.” In Flame Wars: The Discourse of Ccyberculture, edited by Mark Dery, 179-222. Durham: Duke University Press, Ellison, Ralph. 1952. Invisible Man. New York: Signet Books. 
Eshun, Kodwo. 1998. More Brilliant than the Sun. London: Quartet Books.

Fisher, Mark. 2009 Capitalist Realism: Is There No Alternative? London: Zero Books.

Fraser, Andrea. 2005. "From the Critique of the Institution to an Institution of Critique." Artforum 44 (1): 278-83.

Gibson, James J. 1950. The Perception of the Visual World. New York: Houghton Mifflin.

Gielen, Pascal and De Bruyne, Paul. 2009. Being and Artist in Post-Fordist Times. Rotterdam: NAi Publishers.

Gramsci, Anonio. 1971. Selection from the Prison Notebooks. London: Lawrence and Wishart.

Hall, Stuart. 2011. “The Neo-Liberal Revolution.” Cultural Studies 25 (6): 705-728. . 2017. Familiar Stranger: A Life Between Two Islands. Durham: Duke University Press.

Haraway, Donna. 1991. Simians, Cyborgs and Women: The Reinvention of Nature. London: Free Association Books.

Harvey, David. 2010. The Enigma of Capital: And the Crisis of Capitalism. London: Enigma books.

Hopkins, Nalo. 2005. Address Given at the College of New Jersey, Department of African- American Studies, Thirtieth Anniversary Symposia: “Afrofuturism: Womanist Paradigms for the New Millennium.” Femspec 6 (1): 103-113.

Invisible Committee. 2009. The Coming Insurrection. No place of publication: Self Published.

Johnson-Small, Jamila. 2016a. “One Big Fist.” January 19, 2016. Last Yearz Interesting Negro Blog. Accessed October 25, 2016. https://jamilajohnsonsmall.wordpress.com /2016/01/19/one-big-fist/. . 2016b. “...All my Education has been Misleading." March 2, 2016. Last Yearz Interesting Negro Blog. Accessed May 27, 2017. $<$ https://jamilajohnsonsmall.wordpress.com/2016/03/02/all-my-education-hasbeen-misleading/.

Laermans, Rudi. 2015. Moving Together: Theorizing and Making Contemporary Dance. Amsterdam: Valiz.

Lefebvre, Henri. 1991. The Production of Space. Oxford: Blackwell. 
Lepecki, André. 2007. "Choreography as Apparatus of Capture.” The Drama Review 51(2) T194: 120-23.

Lepecki, André. 2016. Singularities: Dance in the Age of performance. Abingdon: Routledge.

Massey, Doreen. 1994. Space, Place, and Gender. Cambridge: Polity Press.

Massumi, Brian. 2015. Politics of Affect. Cambridge: Polity Press.

Moten, Fred. 2003. In the Break: The Aesthetics of the Black Radical Tradition. Minneapolis: Minnesota University Press.

Phelan, Peggy. 1993. Unmarked: The Politics of Performance. London and New York: Routledge.

Project O. 2017. Voodoo. (performance program) Lillian Baylis Studio, Sadler's Wells Theatre, London.

Rand, Ayn. 1989. The Voice of Reason. New York: New American Library.

Rifkin, Jeremy. 2000. The Age of Access: How the Shift from Ownership to Access is Transforming Modern Life. London: Penguin Books.

Rose, Gillian. 1993. "Some Notes towards Thinking about the Spaces of the Future." In Mapping the Futures: Local Cultures, Global Change, edited by John Bird, Barry Curtis, Tim Putman, George Robertson, and Lisa Tickner, 70-83. London: Routledge.

Schumpeter, Joseph. 1942. Capitalism Socialism and Democracy. New York: Harper \& Bloom.

Turow, Joseph. 2011. The Daily You: How the New Advertising Industry is Defining Your Identity and Your Worth. New Haven, CT: Yale University Press.

Uzor, Tia-Monique. (2018) 'Negotiating African Diasporic Identity Through Dance, brown bodies creating and existing in the British dance industry' in Narratives in Black British Dance: Embodied Practices edited by Adesola Akinleye.

Basingstoke: Palgrave, pp. 37-50.

Wookey, Sara. ed. 2015. Who Cares? Dance in the Gallery and Museum. London: Siobhan Davies Dance. 